\title{
VALIDATION OF 10 MICROSATELLITE LOCI FOR THEIR USE IN PARENTAGE VERIFICATION AND INDIVIDUAL IDENTIFICATION IN THE YUGOSLAVIAN SHEPHERD DOG SHARPLANINA*
}

\author{
Vladimir Dimitrijevic ${ }^{1}$, Jevrosima Stevanovic ${ }^{2}$, Mila Savic ${ }^{1}$, \\ Branko Petrujkic ${ }^{3}$, Predrag Simeunovic ${ }^{2}$, Ivan Milosevic ${ }^{2}$, \\ Zoran Stanimirovic ${ }^{2}$
${ }^{1}$ Department of Animal Breeding and Genetics, Faculty of Veterinary Medicine,
${ }^{2}$ Department of Biology, Faculty of Veterinary Medicine, ${ }^{3}$ Department of Nutrition and Botany, Faculty of Veterinary Medicine, University of Belgrade, Bul. oslobodjenja 18, 11000 Belgrade, Serbia
•Corresponding author: vanja@vet.bg.ac.rs

\begin{abstract}
The aim of the study was to assess a commercially available microsatellite panel for use in paternity and identification analyses in the Yugoslavian Shepherd Dog Sharplanina, an ancient livestock guarding breed. Allele frequencies for 10 microsatellite loci (PEZ01, FHC2054, FHC2010, PEZ05, PEZ20, PEZ12, PEZ03, PEZ06, PEZ08 and FHC2079) were determined in 103 unrelated Yugoslavian Shepherd Dog individuals. The loci revealed varied levels of polymorphism (five to 12 alleles), with an average of 7.83 per locus. Average values of observed heterozygosity and polymorphic information content (PIC) were $\mathbf{0 . 6 4}$ and $\mathbf{0 . 6 6}$, respectively. Nine out of 10 microsatellite markers were highly informative with PIC values higher than 0.5 . The obtained value of combined power of exclusion (0.9989) confirms usefulness of this panel of microsatellites for parentage verification, while the value of combined power of discrimination of 0.9999 clearly shows that the panel can conclusively identify individual dogs. In conclusion, the results obtained suggest that the selected set of commercially available microsatellite markers may be used as a routine tool for parentage verification and individual identification in the Yugoslavian Shepherd Dog. Although analysis of genetic variability of the Yugoslavian Shepherd Dog was not the primary focus of the study, the established values of major diversity indices disclose a highly variable gene pool in the breed.
\end{abstract}

Key words: dog, canine microsatellites, allele frequency, parentage testing

Intensive artificial selection has led the domestic dog (Canis familiaris) to become the most morphologically diverse mammal species, encompassing more than

\footnotetext{
*This study was financed from funds of the Ministry of Education, Science and Technological Development of the Republic of Serbia, project No. III46002.
} 
400 breeds (Parker et al., 2004). The pure breeds display high levels of genetic homogeneity, and the risks of inbreeding depression and hereditary defects are clearly enhanced (Parker et al., 2004). Therefore, a reliable parentage verification and identification system is needed in order to execute effective breeding strategy, avoid inherited conditions, and contribute to the integrity of pure breeds.

Molecular genetic techniques are used in most domesticated animals to verify identity, to establish familial relatedness, and, in particular, to validate registries (Nechtelberger et al., 2001; Lipinski et al., 2007). Short tandem repeats (STR) or microsatellites are genetic markers commonly used for paternity testing and genetic variability studies (Stevanovic et al., 2010; Jakubczak et al., 2011; JeżewskaWitkowska et al., 2012). Multiplex PCR coupled with electrophoresis of fluorescent labelled PCR products have increased the efficiency of using microsatellites for parentage and identification testing (Radko and Słota, 2007; Radko, 2008). A large number of highly polymorphic microsatellites are now characterized and mapped in dogs (Francisco et al., 1996; Litt et al., 2005; Asch et al., 2009), facilitating their use in parentage testing. They are used either as in-house assembled and optimized microsatellite panels (Zajc et al., 1994; Altet et al., 2001; Eichmann et al., 2004, Kang et al., 2009; Asch et al., 2009), or as kits originally developed for paternity testing and forensic applications (De Nise et al., 2004; Pribanova et al., 2009; Tom et al., 2010; Ogden et al., 2012). Although DNA typing has become a standard tool for verifying the parentage and identification of individual dogs in a large number of countries, it has not been routinely used for these purposes in Serbia so far. To our knowledge, this is the first report of microsatellite characterization in a dog breed in Serbia.

The Yugoslavian Shepherd Dog Sharplanina is an ancient livestock guarding breed. The true origin of the breed is not completely known. It is believed that the ancestors of the Yugoslavian Shepherd Dog were brought to Europe from Asia in prehistoric times through mass migrations. The breed was first recognized by the Fêdêration Cynologique Internationale (FCI) in 1939 under the designation Illyrian Shepherd. In 1957 the name of the breed was changed to Yugoslavian Shepherd Dog Sharplanina. Previously, genetic investigations of this dog breed comprised analysis of blood proteins and enzyme polymorphism (Dimitrijevic et al., 2005, 2007). This study was aimed at assessing a commercially available microsatellite panel for parentage verification and individual identification in the Yugoslavian Shepherd Dog.

\section{Material and methods}

The study population included 103 unrelated Yugoslavian Shepherd Dog animals. Buccal swab samples and pedigree records were collected at national breed club specialty dog shows held in 2007 and 2008 and at the Center for Dog Training Niš. The animals selected for the survey were unrelated by at least one generation, as confirmed by their pedigree records. DNA isolation from buccal epithelial cells was performed following the transport from the field site, using the conventional phenol/ 
chloroform method (Sambrook and Russell, 2001). Concentration of extracted DNA was determined spectrophotometrically (BioPhotometer, Eppendorf). Stock DNA was stored at $-20^{\circ} \mathrm{C}$.

The 10 microsatellite loci (PEZ01, FHC2054, FHC2010, PEZ05, PEZ20, PEZ12, PEZ03, PEZ06, PEZ08 and FHC2079) were genotyped by the StockMarks ${ }^{\circledR}$ Dogs Genotyping kit (Applied Biosystems), under conditions recommended by the manufacturer. Amplification was performed in a Gene Amp PCR System 9700 (Applied Biosystems). The fluorescent tagged PCR products were separated by capillary electrophoresis conducted on an ABI Prism 310 Genetic Analyser (Applied Biosystems), using the GeneScan-350 ROX Size Standard (Applied Biosystems) in accordance with the manufacturer's specifications. DNA fragment size was analysed by GeneScan ${ }^{\circledR}$ and Genotyper ${ }^{\circledR}$ software (Applied Biosystems).

Basic diversity indices such as the number of alleles $\left(n_{A}\right)$, allele frequencies, observed and expected heterozygosity ( $H_{o}$ and $H_{e}$, respectively), were computed for all markers tested using Arlequin ver. 3.1 software (Excoffier et al., 2006). Possible deviations from Hardy-Weinberg equilibrium (HWE) were determined using the exact test (Guo and Thompson, 1992). Corrections for multiple significance tests were performed by applying a Bonferroni-Holm correction (Holm, 1979). Polymorphic information content (PIC) of different microsatellites used in the present study was estimated according to the formula reported by Botstein et al. (1980). Power of exclusion (PE) and power of discrimination (PD) were calculated for each microsatellite marker, while combined PE and combined PD were calculated for the whole set of markers. PE was calculated with an assumption of knowing one parent (Jamieson and Taylor, 1997). PE and PD were determined by using PowerStats ver. 1.2 freeware (Promega Corporation, USA).

\section{Results}

Summarized characteristics of microsatellite markers analysed in the present study are shown in Table 1 . The total number of observed alleles in our study population was 78 with an average of 7.83 per locus. The $n_{A}$ varied from 5 (FHC2010, PEZ05) to 12 (PEZ03) across different loci. The mean $H_{o}$ in the Yugoslavian Shepherd Dog was estimated to be 0.638 , while mean $H_{e}$ was 0.702 . Tests for deviation from HWE showed a highly significant $(\mathrm{P}<0.005)$ difference between observed and expected genotype frequencies at one locus only, namely FHC2079. The PIC was smallest for the locus PEZ03 (0.48) and largest for PEZ12 (0.82), while the mean value of this parameter was 0.66 . Nine out of 10 microsatellite markers were highly informative with PIC values of more than 0.5 . The most polymorphic loci were PEZ12, PEZ06 and PEZ08, and they exhibited high $n_{A}$ and high $H_{o}, H_{e}$ and PIC values. In addition, frequency of the most frequent allele (FNA) across these loci was well below 0.5 (Table 1). As far as paternity testing is concerned, the PE ranged from 0.135 (PEZ03) to 0.539 (PEZ08) per locus. The whole panel of 10 microsatellites reached a high combined $P E$ value of 0.9989 (Table 2). 
Table 1. Characteristics of the investigated microsatellite loci in the Yugoslavian Shepherd Dog

\begin{tabular}{l|c|c|c|c|c|c|c}
\hline $\begin{array}{c}\text { Microsatellite } \\
\text { marker }\end{array}$ & $\begin{array}{c}\text { Observed size } \\
\text { range (bp) }\end{array}$ & $n_{A}$ & $F N A$ & $H_{o}$ & $H_{e}$ & HWE & PIC \\
\hline PEZ01 & $105-125$ & 6 & 0.386 & 0.65347 & 0.74578 & 0.29382 & 0.70 \\
FHC2054 & $144-176$ & 9 & 0.471 & 0.71845 & 0.72067 & 0.37251 & 0.69 \\
FHC2010 & $219-235$ & 5 & 0.563 & 0.51456 & 0.57248 & 0.00580 & 0.50 \\
PEZ05 & $96-112$ & 5 & 0.480 & 0.57426 & 0.64130 & 0.02233 & 0.57 \\
PEZ20 & $163-191$ & 7 & 0.426 & 0.66019 & 0.72740 & 0.17231 & 0.68 \\
PEZ12 & $261-301$ & 10 & 0.240 & 0.73000 & 0.84000 & 0.01310 & 0.82 \\
PEZ03 & $103-139$ & 12 & 0.691 & 0.43299 & 0.50558 & 0.08701 & 0.48 \\
PEZ06 & $171-219$ & 10 & 0.275 & 0.75490 & 0.81054 & 0.73371 & 0.78 \\
PEZ08 & $218-246$ & 8 & 0.316 & 0.76699 & 0.78049 & 0.48234 & 0.74 \\
FHC2079 & $262-290$ & 6 & 0.432 & 0.57282 & 0.67866 & $0.00051 *$ & 0.63 \\
Mean & & 7.8 & 0.428 & 0.63786 & 0.70229 & & 0.659 \\
\hline
\end{tabular}

$\mathrm{n}_{\mathrm{A}}=$ number of alleles.

FNA $=$ frequency of the most frequent allele.

$\mathrm{H}_{\mathrm{o}}=$ observed heterozygosity.

$\mathrm{H}_{\mathrm{e}}=$ expected heterozygosity.

$\mathrm{PIC}=$ polymorphism information content.

$* \mathrm{P}<0.005$, significantly deviated from Hardy-Weinberg equilibrium (HWE).

Table 2. Values of power of exclusion (PE), combined power of exclusion (CPE), power of discrimination (PD) and combined power of discrimination (CPD) for the examined 10 loci in the Yugoslavian Shepherd Dog

\begin{tabular}{l|l|c|c}
\hline No. & $\begin{array}{c}\text { Microsatellite } \\
\text { marker }\end{array}$ & PE & PD \\
\hline 1 & PEZ01 & 0.360 & 0.893 \\
2 & FHC2054 & 0.457 & 0.881 \\
3 & FHC2010 & 0.201 & 0.729 \\
4 & PEZ05 & 0.261 & 0.808 \\
5 & PEZ20 & 0.379 & 0.879 \\
6 & PEZ12 & 0.476 & 0.948 \\
7 & PEZ03 & 0.135 & 0.722 \\
8 & PEZ06 & 0.518 & 0.935 \\
9 & PEZ08 & 0.539 & 0.912 \\
10 & FHC2079 & 0.192 & 0.839 \\
& & CPE $=0.9989$ & CPD $=0.9999$ \\
\hline
\end{tabular}

\section{Discussion}

The Yugoslavian Shepherd Dog is one of the most popular breeds in the region, and several national breed clubs have been founded over the past decades in Yugoslavia. However, comprehensive and reliable breeding records are not fully accessible, which is partially due to the breakup of Yugoslavia. The breed is indigenous to the Sharplanina Mountain region, which was once a Yugoslavian territory, but now belongs to different states. Consequently, the Yugoslavian Shepherd Dog is currently 
considered as an autochthonous breed in Serbia, Kosovo and Former Yugoslav Republic of Macedonia (FYROM). It should also be noted that a number of dogs bred in wild and isolated parts of the Sharplanina Mountain have not been registered at all. In this study, only dogs registered by the Kennel Club of Republic Serbia were included, which somewhat limits the representativeness of the sample for the fragmented and isolated populations of the Yugoslavian Shepherd Dog in the region.

The present study was designed to evaluate 10 commercially available microsatellite markers for their information content and ability to discriminate individuals and verify parentage in the Yugoslavian Shepherd Dog. We used the StockMarks ${ }^{\circledR}$ Dogs Genotyping kit for two reasons. First, standardized kits are supposed to enable reliable parentage testing results and do not require as stringent optimization as inhouse panels of genetic markers. Second, the kit has been recommended for routine canine parentage testing, but its accuracy and reliability may be variable in different breeds (DeNise et al., 2004). Ten microsatellite markers used in this study were also among those analysed in arctic foxes (Jakubczak et al., 2009), although with regard to the productive traits of fur-bearing animals.

The results of microsatellite polymorphism observed in this study have already been reported by previous studies that analysed the same set of markers (DeNise et al., 2004; Volkel, 2005; Pribanova et al., 2009; Zenke et al., 2011). For example, our results for high polymorphism of loci PEZ12, PEZ06 and PEZ08 are in agreement with the results of DeNise et al. (2004) who found the same loci among the most informative (with 24, 22 and 14 alleles, respectively) in a population of $9561 \mathrm{dogs}$ representing 108 breeds. The same study recognized PEZ03 as the most informative marker with an average number of 6.7 alleles per breed. In the Yugoslavian Shepherd Dog, however, the locus PEZ03 had the maximal number of alleles, but it displayed the lowest value of other basic diversity indices. We established characteristic distribution of allele frequencies for this locus, i.e. obvious predominance of one allele with frequency of 0.691 . In addition to the PEZ03, the least informative loci in the Yugoslavian Shepherd Dog were FHC2010 and PEZ05. This finding was also in accordance with results of previous studies (DeNise et al., 2004; Volkel, 2005; Pribanova et al., 2009; Zenke et al., 2011).

The high value of combined PE (0.9989) observed in the population of the Yugoslavian Shepherd Dog corresponds to the combined PE reported by previous studies that used identical panel of microsatellite markers in other dog breeds: 0.9955 (Pribanova et al., 2009) and 0.9999 for Dachshund (Zenke et al., 2011); 0.9904 for German Shepherd (Zenke et al., 2011); 0.9942 for Rottweiler (Zenke et al., 2011); and 0.9998 for Schnauzer (Zenke et al., 2011). Moreover, the combined PE value established in this study corresponds to the value recommended for the accurate parentage testing in dogs (Halverson and Edwards, 2000). The next issue of interest was capacity of 10 microsatellite markers for individual identification of Yugoslavian Shepherd Dogs. Reliable DNA-based individual identification of dogs is important for successful breeding strategies, but it has also become a useful tool in forensically relevant cases involving these animals (Halverson and Basten, 2005). The panel of 10 microsatellites evaluated in the present study has already been effectively used for these purposes (Padar et al., 2002; Halverson and Basten, 2005). The panel also 
achieved high combined PD value of 0.9999 , which clearly demonstrates that the panel can conclusively identify individuals of the Yugoslavian Shepherd Dog breed.

In conclusion, the results obtained in the present study show that the selected set of commercially available microsatellite markers may be used as a routine tool for parentage verification and individual identification in the Yugoslavian Shepherd Dog. In addition, the report of allele distribution may serve as a reference database for future parentage and identity testing for the breed. Although the study was primarily focused on practical applications of microsatellite loci analysis in the Yugoslavian Shepherd Dog, namely parentage and identity testing, it also provided the first insight into genetic variability of the breed.

\section{Acknowledgements}

The authors are grateful to the Ministry of Education, Science and Technological Development of the Republic of Serbia for funding this work (project no. III46002).

\section{References}

A 1 t e t L., F r a n c in o O., S a n c he s A. (2001). Microsatellite polymorphism in closely related dogs. J. Hered., 92: 276-279.

Asch B. van, Alves C., Gusmao L., Pereira V., Pereira F., Amorim A. (2009). A new autosomal STR nineplex for canine identification and parentage testing. Electrophoresis, 30: $417-423$.

B o t s t e in D., W h i te R.L., S k o ln i c k M., D a v is R.W. (1980). Construction of a genetic linkage map in man using restriction fragment length polymorphisms. Am. J. Hum. Genet., 32: 314-331.

DeNise S., Johnston E., Halverson J., Marshall K., Rosenfeld D., McKenna S., S harp T., Edwards J. (2004). Power of exclusion for parentage verification and probability of match for identity in American kennel club breeds using 17 canine microsatellite markers. Anim. Genet., 35: 14-17.

Dimitrijevi c V., Jovanovic S., S avi c M., Trailovic R. (2005). Genetic polymorphism of blood proteins in Yugoslav shepherd dog. Acta Vet.-Beograd, 55: 357-365.

Dimitrijevic V., Jovanovic S., Savic M., Trailovic R. (2007). Efficiency of blood protein systems as genetic markers for parentage verification in Yugoslav shepherd dog. Acta Vet.-Beograd, 57: 81-86.

E i c hmann C., B e r ger B., P a r s o n W. (2004). A proposed nomenclature for 15 canine-specific polymorphic STR loci for forensic purposes. Int. J. Legal Med., 118: 249-266.

Ex c offier L., Laval G., Schneider S. (2006). Arlequin ver 3.1 user manual. Available at: http://cmpg.unibe.ch/software/arlequin3

Francis co L.V., Langsten A.A., Mellersh C.S., Neal C.L., Ostrander O.A. (1996). A class of highly polymorphic tetranucleotide repeats for canine genetic mapping. Mamm. Genome, 7: 359-362.

Guo S.W., Thomps on E.A. (1992). Performing the exact test of Hardy-Weinberg proportions for multiple alleles. Biometrics, 48: 361-372.

H a lve r s o n J.L., E d w a rd s J.W. (2000). Microsatellite polymorphism in dog breeds - the AKC Parent Club study. Proc. XXVII ISAG International Conference on Animal Genetics, 22-26.07.2000, Minneapolis, USA, p. 19.

H a lve r s o n J.L., B a s t e n C. (2005). Forensic DNA identification of animal-derived trace evidence: tools for linking victims and suspects. Croat. Med. J., 46: 598-605.

H o $1 \mathrm{~m} \mathrm{S.} \mathrm{(1979).} \mathrm{A} \mathrm{simple} \mathrm{sequentially} \mathrm{rejective} \mathrm{multiple} \mathrm{test} \mathrm{procedure.} \mathrm{Scand.} \mathrm{J.} \mathrm{Stat.,} \mathrm{6:} \mathrm{65-75.}$

Jakubczak A., Kna ga S., Jeżewska-Witkowska G. (2009). Genetic variation of microsatellite sequences and its relationship with some productive traits of arctic foxes. Ann. Anim. Sci., 9: $133-142$. 
Jakubczak A., Bugno-P oniewierska M., Jeżewska-Witkowska G., Horecka B., B u ś - K i c m a n M. (2011). Genetic differentiation of intergeneric hybrids of Blue Frost foxes and their original forms based on microsatellite polymorphism. Ann. Anim. Sci., 11: 219-227.

J a mi e s o n A., Ta y l or S.C. (1997). Comparisons of three probability formulae for parentage exclusion. Anim. Genet., 28: 397-400.

Jeżewska-Witkowska G., Horecka B., Jakubczak A., Kasperek K., Ślaska B., Bugno-Poniewierska M., Piórkowska M. (2012). Genetic variability of farmed and free-living populations of red foxes (Vulpes vulpes). Ann. Anim. Sci., 12: 501-512.

Kang B.T., Kim K.S., Min M.S., Chae Y.J., Kang J.W., Yoon J., Choi J., S e ong J.K., Park H.C., A n J., L e e M.H., P ark H.M., L e e H. (2009). Microsatellite loci analysis for the genetic variability and the parentage test of five dog breeds in South Korea. Genes Genet. Syst., 84: $245-251$.

Li piński M.J., Amigues Y., Blas i M., Broad T.E., Cherbonnel C., Cho G.J., Corley S., Daftari P., Delattre D.R., Dileanis S., Flynn J.M., Grattapaglia D., Guthrie A., Harper C., Karttunen P.L., Kimura H., Lewis G.M., Longeri M., Meriaux J.C., Morita M., Morrin-O'Donnell R.C., Niini T., Pedersen N.C., Perrotta G., Polli M., Rittler S., Schubbert R., Strillacci M.G., Van Haeringen H., Van Ha eringen W., Ly on s L.A. (2007). An international parentage and identification panel for the domestic cat (Felis catus). Anim. Genet., 38: 371-377.

L itt M., B e s tw i ck M.L., W in ther M.J., J a k obs P.M. (2005). Fifty-four new gene-based canine microsatellite markers. J. Hered., 96: 843-846.

Nechtelberger D., Kaltwasser C., Stur I., Meyer J.N., Brem G., Mueller M., $\mathrm{Mu} 11$ e r S. (2001). DNA microsatellite analysis for parentage control in Austrian pigs. Anim. Biotechnol., 12: 141-144.

Ogden R., Mella nby R.J., Clements D., Gow A.G., Pow el1 R., McEwing R. (2012). Genetic data from 15 STR loci for forensic individual identification and parentage analyses in UK domestic dogs (Canis lupus familiaris). Forensic Sci. Int.-Gen. 6: 63-65.

Padar Z., Egyed B., Kontadakis K., Furedi S., Woller J., Zoldag L., Fekete S. (2002). Canine STR analyses in forensic practice. Observation of a possible mutation in a dog hair. Int. J. Legal Med., 116: 286-288.

P a rke r H.G., K i m L.V., S u t t e r N.B., C arls on S., L or entzen T.D., Mal ek T.B., Johns on G.S., D e France H.B., Ostrander E.A., Kruglyak L. (2004). Genetic structure of the purebred domestic dog. Science, 304: 1160-1164.

Pribanova M., Horak P., Schroffelova D., Urban T., Bechynova R., Musilov a L. (2009). Analysis of genetic variability in the Czech Dachshund population using microsatellite markers. J. Anim. Breed. Genet., 126: 311-318.

Radko A., Słota E. (2007). Polymorphism of 11 microsatellite DNA sequences used for parentage control in Holstein-Friesian bulls of black-and-white variety in Poland. Ann. Anim. Sci., 7: $189-196$.

R a d k o A. (2008). Microsatellite DNA polymorphism and its usefulness for pedigree verification of cattle raised in Poland. Ann. Anim. Sci., 8: 311-321.

S a mbrook J., R us s e 11 D.W. (2001). Editors. Molecular Cloning: A laboratory manual. 2nd Ed. Cold Spring Harbor Laboratory Press, New York.

Stevanovic J., Stanimirovic Z., Dimitrijevic V., Maletic M. (2010). Evaluation of 11 microsatellite loci for their use in paternity testing in the Yugoslav Pied cattle (YU Simmental cattle). Czech J. Anim. Sci., 55: 221-226.

Tom B.K., Koskinen M.T., Dayton M., Mattila A.M., Johnston E., F antin D., De Nise S., Spear T., Smith D.G., Satkoski J., Budowle B., Kanthaswamy S. (2010). Development of a nomenclature system for a canine STR multiplex reagent kit. J. Forensic Sci., 55: 597-604.

Volkel I. (2005). Breed identification in Canis familiaris: Various approaches based on molecular genetic studies. PhD Diss. Hannover, Germany, Tierarztlichen Hochschule. 153 pp. Available at: University electronic library, http://elib.tiho-hannover.de/dissertations/voelkeli_ws05.pdf

Zaj c I., Mellers h C., Kelly E.P., S a mps on J. (1994). A new method of paternity testing for dogs, based on microsatellite sequences. Vet. Rec., 135: 545-547. 
Z e n k e P., E g y e d B., Z o ld a g L., P a d a r Z. (2011). Population genetic study in Hungarian canine populations using forensically informative STR loci. Forensic Sci. Int.-Gen., 5: 31-36.

Accepted for printing 29 V 2013

\section{VLADIMIR DIMITRIJEVIC, JEVROSIMA STEVANOVIC, MILA SAVIC, BRANKO PETRUJKIC, PREDRAG SIMEUNOVIC, IVAN MILOSEVIC, ZORAN STANIMIROVIC}

\section{Walidacja 10 loci mikrosatelitarnych do kontroli pochodzenia oraz identyfikacji osobniczej jugosłowiańskiego psa pasterskiego z Szar Planiny}

\section{STRESZCZENIE}

Celem eksperymentu była ocena przydatności komercyjnego panelu markerów mikrosatelitarnych do analizy pochodzenia i identyfikacji osobniczej owczarka jugosłowiańskiego Sarplaninac, starodawnej rasy psów pasterskich. Frekwencje alleli dla 10 loci mikrosatelitarnych (PEZ01, FHC2054, FHC2010, PEZ05, PEZ20, PEZ12, PEZ03, PEZ06, PEZ08 i FHC2079) określono u 103 niespokrewnionych osobników rasy Sarplaninac. W loci ujawniono zróżnicowany poziom polimorfizmu (5 do 12 alleli), wynoszący średnio 7,83 na locus. Średnie wartości heterozygotyczności obserwowanej i współczynnika polimorfizmu (PIC) wyniosły, odpowiednio 0,64 i 0,66. Dziewięć z 10 markerów mikrosatelitarnych było wysoko informatywnych, przy wartościach PIC przekraczających 0,5. Uzyskana wartość skumulowanej siły wykluczenia $(0,9989)$, potwierdza przydatność badanego panelu markerów mikrosatelitarnych do kontroli pochodzenia, natomiast wartość skumulowanej siły dyskryminacji, wynoszącej 0,9999 wyraźnie wskazuje, że panel ten może jednoznacznie identyfikować poszczególne osobniki. Uzyskane wyniki wskazują, że wybrany zestaw komercyjnych markerów mikrosatelitarnych może służyć jako rutynowe narzędzie do kontroli pochodzenia oraz identyfikacji osobniczej jugosłowiańskiego psa pasterskiego. Choć analiza zmienności genetycznej owczarka jugosłowiańskiego nie była głównym celem badań, uzyskane wartości głównych indeksów różnorodności wskazują na występowanie wysoko zróżnicowanej puli genowej w tej rasie. 